\title{
Effect of Wastewaters on Soil Enzymes Activity
}

\author{
Hanamantarao Jogan* and G.S. Dasog \\ Department of Soil Science and Agricultural Chemistry, UAS, Dharwad-580 005, India \\ *Corresponding author
}

\section{Keywords \\ Wastewater, Water quality, Lateritic soil, Red soil, Black Soil, Urease, Phosphatase and Dehydrogenase \\ Article Info \\ Accepted: \\ 10 March 2019 \\ Available Online: \\ 10 April 2019}

\section{A B S T R A C T}

Water scarcity and increase wastewater generation are twin problem associated which needs to be addressed to derive benefit for agricultural production. In this context laboratory study was conducted to characterize the wastewater from four different sources (Ugar sugar-Ugar khurd, West coast paper mill-Dandeli, Nectar beverages-Dharwad, Domestic sewage water-UAS campus Dharwad) in north Karnataka and were compared with freshwater. Spentwash from the Ugar Sugar Works distillery was singularly different from rest of the wastewaters and was characterized by its high $\mathrm{pH}, \mathrm{EC}$, TSS, TDS, BOD, COD, total nitrogen, phosphate, potassium and sulphate concentration. The effect of the wastewaters on the dominant soils of north Karnataka (Red, Lateritic and Black soil) were evaluated in column study during March-2014 to April-2015. Wide variation in water characteristics was recorded with wastewaters studied. Urease, phosphatase and dehydrogenase activities were highest in spent wash treatment in red soil followed by paper mill wastewater in all soils. Activity of urease, phosphatase and dehydrogenase was recorded highest at surface layer and their activity gradually decreased with the depths in all the soils under different treatments.

\section{Introduction}

Increasing scarcity of water has turned to be regular phenomenon in the recent past. Priorities of the water use have also being changing with increased demand from the other sectors creating competition for the water use in agriculture sector. Rapid population increase in urban areas and industrialization gives rise to concern about appropriate water management practices. Surface waters are being polluted by means of wastes or effluent discharge from the industries, domestic sewage, and municipal wastes etc. Further land application of wastewater is now becoming one of the most economically and ecologically viable method of disposal of these waters. With rapid expansion of cities and domestic water supply, quantity of grey/wastewater is increasing in the same proportion. Overall analysis of water resources indicates that in coming years, there will be a twin edged problem to deal with reduced fresh water availability and increased wastewater generation. Non-conventional water resources play greater role for water augmentation to achieve food security in water-scarce 
countries in the near future. Urban agriculture using wastewater provides food, income and employment to thousands of people. Nevertheless, reusing wastewater in agriculture is considered a deleterious practice since it may introduce pollutants to the environment, spread waterborne diseases, chemical contamination, soil salinization and contamination of groundwater sources, generate odour problems and result in aversion to the crops (IWMI, 2006). Contrarily, this kind of reuse may result in some benefits for soils, crops and farmers. Nowadays, the reuse of wastewater in agriculture is seen in some countries as a convenient environmental strategy. Globally around 3 to 3.5 million hectares are irrigated with raw and diluted wastewater irrigation. Wastewater is therefore, considered an appropriate option for reuse. Wastewater contains a significant load of biodegradable organic material and nutrients which are necessary for the growth of crops. Accumulation of organic matter in soil by irrigation with wastewater can be beneficial as it may result in the enhancement of physical structure of the soil, the increase in soil microbial activity and improvement of soil performance as a filter and degrading media for pollutants. The consistent use of wastewater in irrigation may stabilize the content of nutrients in the soil, even when growing crops with high nutritional requirements; this is because the continuous withdrawal of nutrients by plants is compensated by the constant input of organic and mineral components into the soil via wastewater. Effect of sewage wastewater on black soil (Varkey et al., 2015), paper mill wastewater on red soil (Sharma et al., 2014) and spentwash on black soil (Singh and Swami, 2014) have been studied. Composite study on characterization of the wastewater and their effect of different wastewaters on a wide range of soil is sparse. Information on effect of wastewater on a wide range of dominant soils of north Karnataka under controlled laboratory condition would give an insight into their capacity to bear the load of different chemical constituents. Thus a comprehensive study on the effect of different wastewaters characterized by different properties on different soil types was planned and executed under laboratory conditions.

\section{Materials and Methods}

The investigation was carried out by using three dominant soils of north Karnataka viz., Red (Ustropepts), Lateritic (Kanhaplic Haplustalfs), and Black soils (Typic Haplusterts) (Table 1). Four different water sources employed were domestic sewage, paper mill wastewater, soft drink factory wastewater, distillery spentwash and compared with fresh water (borewell water). The wastewater samples were collected from different sources were used for the column study. For the column study $5 \mathrm{~cm}$ diameter PVC pipes of $60 \mathrm{~cm}$ long with perforated bottom end caps were used. Initially the BD of each soil sample was measured, based on the BD and pipe column parameters (length and diameter) the quantity of soil filled in the each soil column was calculated.

Volume of pipe column $=\pi \mathrm{r}^{2} \mathrm{~h}, \mathrm{r}=2.5 \mathrm{~cm}$, $\mathrm{h}=60 \mathrm{~cm}$,

Volume of pipe column $=1178.25 \mathrm{~cm}^{3}$, Weight of soil in column $=$ Volume $\times$ BD

Each soil samples were properly processed and passed through $2 \mathrm{~mm}$ sieve, before filling the columns. Amount water added in each column was based on maximum water holding capacity of different soils. Irrigation was given in terms of pore volumes, totally 8 pore volumes were passed through soil columns at an interval of 10 days. After passing two pore volumes one set of column was horizontally sectioned at an interval of 15 $\mathrm{cm}$. 


\begin{tabular}{|l|l|l|l|l|}
\hline Soils & BD $\left(\mathrm{g} \mathrm{cm}^{-\mathbf{3}}\right)$ & $\begin{array}{l}\text { Quantity of soil } \\
\text { added } \mathbf{( k g})\end{array}$ & MWHC (\%) & $\begin{array}{l}\text { Amount of water added } \\
\text { per one pore volume (ml) }\end{array}$ \\
\hline Red & 1.45 & 1.71 & 48.5 & 828 \\
\hline Lateritic & 1.52 & 1.80 & 50.5 & 903 \\
\hline Black & 1.34 & 1.57 & 67 & 1057 \\
\hline
\end{tabular}

Experiment was conducted using two factorial CRD with three replication. Factor I included different wastewater sources (1. Domestic sewage water- UAS Dharwad, 2. Soft drink factory treated wastewater- Nectar beverages, Dharwad, 3. Paper mill treated wastewaterWest Coast Paper mill Dandeli, 4. Distillery biomethanated spentwash (diluted with normal water in the ratio of 1:3) - Ugar sugar works Ugar khurd and 5. Normal water- Fresh borewell water UAS Dharwad) and factor II comprised of different soil depths $(0-15 \mathrm{~cm}$, $15-30 \mathrm{~cm}, 30-45 \mathrm{~cm}$ and $45-60 \mathrm{~cm})$.

The $\mathrm{pH}$ and $\mathrm{EC}$ of the waters were analyzed immediately after bringing the samples using $\mathrm{pH}$ meter and Systronics direct digital conductivity meter-304, respectively as described by Tandon, 1998. The dissolved solids in the effluents were determined by gravimetric method. The suspended solids in the effluents were determined by filtration method (Tandon, 1998).

The Biological oxygen demand (BOD) of effluents were determined by measuring the dissolved oxygen of the samples before and after incubation at $20^{\circ} \mathrm{C}$ for five days by titrating it against sodium thiosulphate using starch indicator and the BOD of sewage water was calculated as described by Tandon (1998). The Chemical oxygen demand (COD) of wastewater was determined by open reflux method. The total nitrogen in water samples were determined titrimetrically after distilling the $\mathrm{NH}_{3}$ in boric acid mixed indicator. The phosphates in the effluents were determined by chloro-stannous reduced blue colour method. Potassium in the effluents was determined by using the flame photometer with suitable dilutions as described by Tandon (1998).

The $\mathrm{pH}$ of soil was determined in 1: 2.5 soils to water suspension after stirring the samples intermittently for half an hour using a Systronics direct digital $331 \mathrm{pH}$ meter. Electrical conductivity of the soil was determined in the supernatant of 1:2.5 soils to water suspension by using Systronics direct digital conductivity meter-304 (Sparks et al., 1996). The organic carbon content was determined by taking finely ground sample by wet oxidation method as described by Jackson (1967). Available nitrogen was estimated by modified alkaline potassium permanganate method (Sahrawat and Burford, 1982).

Available phosphorus was determined by Olsen's method extracting phosphorus with $0.5 \mathrm{M} \mathrm{NaHCO} 3 \mathrm{pH}$ 8.5. Available potassium was extracted with neutral normal ammonium acetate and the potassium in the solution was estimated by flame photometer (Jackson, 1967). Available sulphur was determined by Turbidometric method described by Sparks $e t$ al., (1996).

Dehydrogenase activity analyzed by $2,3,5$ triphenyl tetrazolium chloride method (Casida et al., 1964). Urease activity analyzed by Nesslers reagent method (Pancholy and Rice, 1973). Phosphatase activity analyzed by using p-nitrophenol phosphate solution (Evasi and Tabatabi, 1979). The experimental data was statistically analyzed as per Gomez and Gomez (1984) for soil physical and chemical properties. The computed data was interpreted with a critical differences level at 1 per cent. 


\section{Results and Discussion}

The $\mathrm{pH}$ of sewage water and the wastewater from paper mill were near neutral whereas those from soft drink factory and distillery biomethanated spentwash were alkaline. The EC of paper mill and soft drink factory wastewaters were around $2 \mathrm{dS} \mathrm{m}^{-1}$ whereas the sewage water was $1.23 \mathrm{dS} \mathrm{m}^{-1}$ closely followed by the normal water of the campus. The spentwash from the Ugar Sugar Works distillery was the most saline with an EC of $11.54 \mathrm{dS} \mathrm{m}^{-1}$ and in many other properties such as TDS, TSS, BOD, COD, Total N, P and $\mathrm{K}$ contents was singularly different from rest of the wastewaters. With respect to total $\mathrm{N}, \mathrm{P}$ and $\mathrm{K}$, the remaining three wastewaters had similar content. The sewage water was characterized by its high TSS, TDS, BOD and COD, the values of which were much less in soft drink factory wastewater and paper mill wastewater except for high TDS and COD (Table 2).

Effect of different wastewater on Soil enzyme activity

Soil enzyme activities were very much influenced by the application of different wastewaters. Higher enzyme activities were noticed in the soils treated with wastewaters. The stimulation of enzymes due to addition of suspended organic material and nutrients to the soil through various wastewater which serves as a source of energy for microbes and enzymes.

Table.1 Initial properties of soils studied

\begin{tabular}{|c|c|c|c|}
\hline Properties & Red soil & Lateritic soil & Black soil \\
\hline pH (1:2.5) & 6.15 & 5.60 & 7.10 \\
\hline EC $\left(\mathbf{d S ~ m}^{-1}\right)$ & 0.14 & 0.28 & 0.21 \\
\hline OC $\left(\mathbf{g ~ k g}^{-1}\right)$ & 8.0 & 4.6 & 4.7 \\
\hline Available- Nitrogen $\left(\mathbf{k g ~ h a}^{-\mathbf{1}}\right)$ & 125.4 & 107 & 213 \\
\hline Available-Phosphorus $\left(\mathbf{k g ~ h a}^{-1}\right)$ & 32.5 & 14.0 & 20.5 \\
\hline Available- Potassium $\left(\mathbf{k g ~ h a}^{-1}\right)$ & 485 & 246 & 457 \\
\hline Available- Sulphur $\left(\mathbf{k g ~ h a}^{-1}\right)$ & 43.5 & 35.0 & 42.0 \\
\hline
\end{tabular}

Table.2 Chemical composition of water samples

\begin{tabular}{|c|c|c|c|c|c|}
\hline Parameters & Sewage & $\begin{array}{c}\text { Soft drink } \\
\text { factory }\end{array}$ & Paper mill & Spentwash & $\begin{array}{c}\text { Normal } \\
\text { water }\end{array}$ \\
\hline pH & 7.33 & 8.14 & 7.4 & 8.3 & 6.91 \\
\hline$E C(d S / m)$ & 1.23 & 2.09 & 1.85 & 11.54 & 0.72 \\
\hline $\operatorname{TSS}\left(\mathrm{mg} \mathrm{L}^{-1}\right)$ & 480 & 18 & 36 & 1115 & 8 \\
\hline TDS $\left(\mathrm{mg} \mathrm{L}^{-1}\right)$ & 662 & 30 & 748 & 1975 & 12 \\
\hline BOD $\left(\mathrm{mg} \mathrm{L}^{-1}\right)$ & 256 & 8.29 & 21 & 1800 & 9 \\
\hline $\operatorname{COD}\left(\mathrm{mg} \mathrm{L}^{-1}\right)$ & 410 & 27 & 158 & 4508 & 14 \\
\hline $\mathrm{Ca}+\operatorname{Mg}\left(\operatorname{meq} L^{-1}\right)$ & 8.6 & 4.8 & 5.6 & 13 & 4.0 \\
\hline Sodium $\left(m e q L^{-1}\right)$ & 6.30 & 6.86 & 7.08 & 8.69 & 3.26 \\
\hline Total-N $\left(\mathrm{mg} \mathrm{L}^{-1}\right)$ & 23.7 & 20.57 & 25.4 & 130.4 & 1.25 \\
\hline Total-P $\left(\mathbf{m g ~ L ~ L}^{-1}\right)$ & 13.45 & 8.25 & 10.34 & 28 & 0.10 \\
\hline Total -K $\left(\right.$ meq $\left.\mathbf{L}^{-1}\right)$ & 0.74 & 0.72 & 1.35 & 39 & 0.20 \\
\hline $\mathrm{NO}_{3}-\mathrm{N}\left(\mathrm{mg} \mathrm{L}^{-1}\right)$ & 1.69 & 1.45 & 1.78 & 2.85 & 0.75 \\
\hline Sulphate $\left(\mathrm{mg} \mathrm{L}^{-1}\right)$ & 7.22 & 7.87 & 8.13 & 9.25 & 2.5 \\
\hline
\end{tabular}


Table.3 Enzymes activity in red and lateritic soils after passing 8 pore volumes of various wastewaters

\begin{tabular}{|c|c|c|c|c|c|c|c|c|c|c|c|c|c|c|c|}
\hline \multicolumn{16}{|c|}{ Red soil } \\
\hline \multirow[t]{2}{*}{ WS } & \multicolumn{5}{|c|}{ Urease $\left(\mu \mathrm{g} \mathrm{NH}_{4}-\mathrm{N} \mathrm{g}^{-1}\right.$ day $\left.^{-1}\right)$} & \multicolumn{5}{|c|}{$\begin{array}{c}\text { Phosphatase ( } \mu \mathrm{g} \text { PNP released } \mathrm{g}^{-1} \\
\text { day }^{-1} \text { ) }\end{array}$} & \multicolumn{5}{|c|}{$\begin{array}{c}\text { Dehydrogenase ( } \mu \mathrm{g} \text { TPF formed } g^{-1} \\
\left.\text { day }^{-1}\right)\end{array}$} \\
\hline & D1 & D2 & D3 & D4 & $\mathbf{M}$ & D1 & D2 & D3 & D4 & $\mathbf{M}$ & D1 & D2 & D3 & D4 & $\mathbf{M}$ \\
\hline W1 & 1.98 & 1.41 & 0.60 & 0.49 & 1.12 & 38.4 & 34.7 & 30.5 & 29.3 & 33.2 & 89.8 & 69.0 & 53.9 & 42.0 & 63.7 \\
\hline W2 & 1.92 & 1.30 & 0.56 & 0.36 & 1.04 & 38.7 & 34.4 & 31.4 & 28.8 & 33.3 & 90.1 & 70.1 & 54.3 & 29.7 & 61.1 \\
\hline W3 & 2.16 & 1.67 & 0.89 & 0.51 & 1.31 & 39.5 & 34.5 & 29.7 & 28.9 & 33.1 & 94.1 & 72.4 & 54.2 & 35.5 & 64.0 \\
\hline W4 & 2.39 & 1.80 & 1.20 & 0.65 & 1.51 & 42.8 & 35.1 & 31.1 & 29.7 & 34.7 & 107.3 & 101.3 & 85.4 & 44.6 & 84.7 \\
\hline W5 & 1.05 & 0.55 & 0.38 & 0.25 & 0.56 & 36.8 & 30.7 & 29.4 & 28.5 & 31.3 & 61.3 & 51.0 & 42.5 & 27.6 & 45.6 \\
\hline Mean & 1.90 & 1.34 & 0.73 & 0.45 & 1.11 & 39.2 & 33.9 & 30.4 & 29.0 & 33.1 & 88.5 & 72.8 & 58.0 & 35.9 & 63.8 \\
\hline \multirow[t]{2}{*}{ W } & \multicolumn{2}{|c|}{ S.Em \pm} & \multicolumn{3}{|c|}{ CD at $1 \%$} & \multicolumn{2}{|c|}{ S.Em \pm} & \multicolumn{3}{|c|}{ CD at $1 \%$} & \multicolumn{2}{|c|}{ S.Em \pm} & \multicolumn{3}{|c|}{ CD at $1 \%$} \\
\hline & \multicolumn{2}{|c|}{0.006} & \multicolumn{3}{|c|}{0.02} & \multicolumn{2}{|c|}{0.041} & \multicolumn{3}{|c|}{0.16} & \multicolumn{2}{|c|}{0.045} & \multicolumn{3}{|c|}{0.17} \\
\hline D & \multicolumn{2}{|c|}{0.006} & \multicolumn{3}{|c|}{0.02} & \multicolumn{2}{|c|}{0.037} & \multicolumn{3}{|c|}{0.14} & \multicolumn{2}{|c|}{0.040} & \multicolumn{3}{|c|}{0.15} \\
\hline $\begin{array}{c}\text { W X } \\
\mathbf{D}\end{array}$ & \multicolumn{2}{|c|}{0.012} & \multicolumn{3}{|c|}{0.05} & \multicolumn{2}{|c|}{0.082} & \multicolumn{3}{|c|}{0.31} & \multicolumn{2}{|c|}{0.090} & & 0.34 & \\
\hline & & & & & & & thit & & & & & & & & \\
\hline W1 & 1.75 & 1.37 & 0.61 & 0.43 & 1.04 & 37.8 & 33.8 & 29.9 & 28.6 & 32.5 & 63.0 & 50.4 & 28.9 & 23.5 & 41.5 \\
\hline W2 & 1.63 & 1.25 & 0.53 & 0.32 & 0.93 & 37.7 & 33.6 & 29.2 & 28.3 & 32.2 & 62.3 & 49.5 & 31.0 & 21.5 & 41.0 \\
\hline W3 & 1.93 & 1.57 & 0.83 & 0.49 & 1.21 & 39.0 & 34.4 & 29.5 & 28.6 & 32.9 & 61.7 & 46.7 & 33.4 & 23.2 & 41.2 \\
\hline W4 & 2.26 & 1.71 & 1.18 & 0.57 & 1.43 & 42.3 & 34.0 & 31.3 & 28.6 & 34.1 & 112.1 & 83.6 & 51.2 & 26.9 & 68.5 \\
\hline W5 & 0.92 & 0.53 & 0.41 & 0.25 & 0.53 & 33.6 & 31.6 & 29.2 & 27.8 & 30.6 & 40.2 & 28.6 & 23.6 & 15.8 & 27.1 \\
\hline Mean & 1.70 & 1.29 & 0.71 & 0.41 & 1.03 & 38.1 & 33.5 & 29.8 & 28.4 & 32.4 & 67.9 & 51.8 & 33.6 & 22.2 & 43.8 \\
\hline $\mathbf{W}$ & & & & $D$ at 1 & & & & & D at 1 & & S.F & $m \pm$ & & $D$ at 1 & \\
\hline & & & & 0.02 & & & & & 0.22 & & & & & 0.42 & \\
\hline D & & & & 0.01 & & & & & 0.20 & & & & & 0.37 & \\
\hline $\begin{array}{c}\text { W X } \\
\text { D }\end{array}$ & & & & 0.03 & & & & & 0.45 & & & & & 0.84 & \\
\hline
\end{tabular}


Table.4 Enzymes activity in black soil after passing 8 pore volumes of various wastewaters

\begin{tabular}{|c|c|c|c|c|c|c|c|c|c|c|c|c|c|c|c|}
\hline \multicolumn{16}{|c|}{ Calcareous soil } \\
\hline \multirow{2}{*}{ WS } & \multicolumn{5}{|c|}{ Urease $\left(\mu \mathrm{g} \mathrm{NH}_{4}-\mathrm{N} \mathrm{g}^{-1}\right.$ day $\left.^{-1}\right)$} & \multicolumn{5}{|c|}{ Phosphatase ( $\mu$ g PNP released $g^{-1}$ day $^{-1}$ ) } & \multicolumn{5}{|c|}{ Dehydrogenase ( $\mu \mathrm{g}$ TPF formed $\mathrm{g}^{-1}$ day $^{-1}$ ) } \\
\hline & D1 & D2 & D3 & D4 & $\mathbf{M}$ & D1 & D2 & D3 & D4 & $\mathbf{M}$ & D1 & D2 & D3 & D4 & $\mathbf{M}$ \\
\hline W1 & 2.09 & 1.75 & 0.95 & 0.59 & 1.34 & 46.2 & 42.5 & 34.7 & 29.5 & 38.2 & 76.5 & 56.4 & 42.6 & 34.1 & 52.4 \\
\hline W2 & 2.08 & 1.69 & 0.73 & 0.53 & 1.26 & 45.6 & 41.7 & 34.4 & 28.5 & 37.6 & 76.5 & 54.7 & 43.2 & 32.7 & 51.8 \\
\hline W3 & 2.22 & 1.78 & 1.13 & 0.67 & 1.45 & 46.4 & 41.9 & 34.7 & 28.6 & 37.9 & 76.4 & 55.1 & 43.3 & 31.6 & 51.6 \\
\hline W4 & 2.47 & 1.96 & 1.28 & 0.78 & 1.62 & 59.6 & 48.2 & 37.2 & 32.5 & 44.4 & 82.6 & 68.2 & 62.4 & 42.4 & 63.9 \\
\hline W5 & 1.48 & 0.71 & 0.56 & 0.41 & 0.79 & 39.4 & 34.6 & 30.1 & 28.7 & 33.2 & 62.0 & 50.0 & 38.6 & 28.6 & 44.8 \\
\hline Mean & 2.07 & 1.58 & 0.93 & 0.60 & 1.29 & 47.4 & 41.8 & 34.2 & 29.5 & 38.2 & 74.8 & 56.9 & 46.0 & 33.9 & 52.9 \\
\hline \multirow[t]{2}{*}{ W } & \multicolumn{2}{|c|}{ S.Em \pm} & \multicolumn{3}{|c|}{ CD at $1 \%$} & \multicolumn{2}{|c|}{ S.Em \pm} & \multicolumn{3}{|c|}{ CD at $1 \%$} & \multicolumn{2}{|c|}{ S.Em \pm} & \multicolumn{3}{|c|}{ CD at $1 \%$} \\
\hline & \multicolumn{2}{|c|}{0.006} & \multicolumn{3}{|c|}{0.02} & \multicolumn{2}{|c|}{0.029} & \multicolumn{3}{|c|}{0.11} & \multicolumn{2}{|c|}{0.039} & \multicolumn{3}{|c|}{0.15} \\
\hline D & \multicolumn{2}{|c|}{0.005} & \multicolumn{3}{|c|}{0.02} & \multicolumn{2}{|c|}{0.026} & \multicolumn{3}{|c|}{0.10} & \multicolumn{2}{|c|}{0.035} & \multicolumn{3}{|c|}{0.13} \\
\hline W X D & \multicolumn{2}{|c|}{0.011} & \multicolumn{3}{|c|}{0.04} & \multicolumn{2}{|c|}{0.058} & \multicolumn{3}{|c|}{0.22} & \multicolumn{2}{|c|}{0.079} & \multicolumn{3}{|c|}{0.30} \\
\hline
\end{tabular}


The phosphatase activity differed from soil to soils. The activity of phosphatase in red soil ranged from 31.3 to $34.7 \mu \mathrm{g}$ PNP released $\mathrm{g}^{-1}$ day $^{-1}$ under different treatments (Table 3). Highest phosphatase activity was observed in $\mathrm{W}_{4}$ treatment $\left(34.7 \mu \mathrm{g}\right.$ PNP released $\mathrm{g}^{-1}$ day $\left.^{-1}\right)$ followed by $\mathrm{W}_{2}\left(33.3 \mu \mathrm{g}\right.$ PNP released $\mathrm{g}^{-1}$ day $\left.^{-1}\right)$ with least activity in $\mathrm{W}_{5}(31.3 \mu \mathrm{g}$ PNP released $\mathrm{g}^{-1}$ day $^{-1}$ ) the sequence observed was $\mathrm{W}_{4}>\mathrm{W}_{2}=\mathrm{W}_{1}=\mathrm{W}_{3}>\mathrm{W}_{5}$ in red soil, $\mathrm{W}_{4}>\mathrm{W}_{3}>\mathrm{W}_{1}>\mathrm{W}_{2}>\mathrm{W}_{5}$ in lateritic soil (Table 3) and $W_{4}>W_{1}>W_{3}>W_{2}>W_{5}$ in calcareous black soils (Table 4). Higher activity of the phosphatase was observed at surface layer and gradually decreased with depths in all the soils under different treatments.

The dehydrogenase activity under various treatments varied among the soils. In red soil the dehydrogenase activity ranged from (45.6 to $84.7 \mu \mathrm{g}$ TPF formed $\mathrm{g}^{-1}$ day $^{-1}$ ). The highest dehydrogenase activity was observed in $\mathrm{W}_{4}$ in all the soils followed by other three wastewaters whose values varied in a narrow range. The general sequence observed was $\mathrm{W}_{4}>\mathrm{W}_{3}>\mathrm{W}_{1}>\mathrm{W}_{2}>\mathrm{W}_{5}$ in red soil (Table 3), $\mathrm{W}_{4}>\mathrm{W}_{3}=\mathrm{W}_{2}=\mathrm{W}_{1}>\mathrm{W}_{5}$ in lateritic and calcareous black soils. The dehydrogenase activity was also highest at the surface layer and decreased gradually with depth in all the soils and in all the treatments (Table $3 \& 4$ ). Kaushik et al., (2005) reported that soil dehydrogenase activity and urease activity were significantly improved in post methanated effluent irrigated soil as compared to control sodic soil. Addition of organic matter along with effluent seems to be the main factor for stimulating dehydrogenase in effluent irrigated soil. Higher activities of all enzymes in polluted soil could be due to the presence of carbon and other nutrients in polluted soil (Narasimha et al., (2011).

In conclusion, urease, phosphatase and dehydrogenase activities were highest in spentwash treatment in red soil followed by paper mill wastewater in all soils. Activity of urease, phosphatase and dehydrogenase was recorded highest at surface layer and their activity gradually decreased with the depths in all the soils under different treatments.

\section{References}

Casida, L. E., Klein, D. A. and Santoto, T., Soil dehydrogenase activity. Soil Sci., 98: 371-376 (1964).

Evasi, F. and Tabatabi, M. A., Phosphatase in soil. Soil Biol. Biochem., 9: 167-172 (1979).

Gomez, K. A. and Gomez, A. A., Statistical Procedures for Agricultural Research. John Willey and Sons, New York, USA (1984).

IWMI, Recycling realities: Managing health risk to make wastewater use an asset. Water policy briefing, issue 17 (2006).

Jackson, M. L., Soil Chemical Analysis. Prentice Hall of India Private Ltd, New Delhi (1967).

Kaushik, A., Nisha, R., Jagjeeta, K. and Kaushik, C. P., Impact of long and short term irrigation of a sodic soil with distillery effluent in combination with bio-amendments. Bio Resource Tech., 96: 1860-1866 (2005).

Narasimha, G., Sridevi, A., Reddy, V. and Reddy, B. R., Effects of cotton ginning mill effluents on soil enzymatic activities and nitrogen mineralization in soil. J. Chem. Pharmaceut. Res., 3:128137 (2011).

Pancholy, S. K. and Rice, E. L., Soil enzymes in relation to old field succession: Amylase, invertase, cellulose, dehydrogenase and urease. Soil Sci. Soc. American Proc., 37: 47-50 (1973).

Sahrawat, K.L. and Burford, J. R., Modification in the alkaline permanganate method for assessing the availability of soil nitrogen in upland soils. Soil Sci., 133(1-6): 53-57 (1982). 
Sharma, V., Umesh, K. G. and Deepak Arora., Impact of pulp and paper mill effluent on physico-chemical properties of soil. Arch. Appl. Sci. Res., 6 (2): 1217 (2014).

Singh, S.V. and Swami, V. K., Impact of distillery wastewater irrigation on chemical properties of agriculture soil. Int. J. Innovative Res. Sci. Engg. Tech., 3 (10): 17028-17032 (2014).

Sparks, D. L., Page, A. L., Helmake, P. A., Loppert R. H., Soltanpour, P. N., Tabatabai, M. A., Johnston, C. T. and
Summer, M. E., Methods of Soil Analysis, Part 3, pp. 610-624 (1996).

Tandon, H. L. S., Methods of Analysis of Soils, Plants, Water and Fertilizers. Fert. Dev. and consultation Org., New Delhi, India, pp. 9-16 (1998).

Varkey, B. K., Dasog, G. S., Wani, S. P., Sahrawat, K. L., Hebbara, M. and Patil, C. R., Impact of long-term application of domestic sewage water on soil properties around Hubli city in Karnataka, India. Agril. Res., 4(3): 272276 (2015).

\section{How to cite this article:}

Hanamantarao Jogan and Dasog, G.S. 2019. Effect of Wastewaters on Soil Enzymes Activity. Int.J.Curr.Microbiol.App.Sci. 8(04): 1080-1087. doi: https://doi.org/10.20546/ijcmas.2019.804.125 